23. Merleau-Ponty, M. (2010). Phenomenology of perception: an introduction. London: Routledge [in English].

24. Pallasmaa, J. (2005). The Eyes of the Skin: Architecture and the Senses.Chichester: Wiley [in English].

25. Rodaway, P. (1994). Sensuous geographies: body, sense and place. London: Routledge [in English].

26. Tester, K. (2015). The Flâneur. London: Routledge [in English].

27. Tukova, I. (2010). The art of music of the second half of XX - the beginning of XXI century: the problem of listeners' perception. Kyivske muzykoznavstvo, [online] 33, pp. 42-47. Available at: http://www.glierinstitute.org/ukr/digests/033/5.pdf [Accessed 21 March 2019] [in English].

28. Vilkner, N. (2016). Sounding streets: Music and Urban Change in Paris, 1830-1870. PhD thesis. The State University of New Jersey. New Jersey [in English].

УДК 785.11 “185/195”: 75“185/195”

DOI: https://doi.org/10.33643/kmus.2019.59.13

Майя Кірдеєва,
апірантка кафедри теорї та історії культури
Національної музичної академії України ім. П. I. Чайковського
https://orcid.org/0000-0001-9756-0909
mayakirdeeva@gmail.com
Maya Kirdeeva,
Postgraduate at the Department of Theoryand History of Culture,
Ukrainian National Tchaikovsky Academy of Music
https://orcid.org/0000-0001-9756-0909
mayakirdeeva@gmail.com

\title{
КАРТИНА АРНОЛЬДА БЕКЛІНА «ОСТРІВ МЕРТВИХ» ЯК ВІДКРИТИЙ ТВІР У МУЗИЧНІЙ КУЛЬТУРІ МЕЖІ ХІХ-ХХ СТОЛІТЬ
}

Суттєва зміна векторів нашого сприйняття та, відповідно, розуміння та пояснення культурних процесів різних часів стимулювали пошук нових, неочевидних зв’язків між мистецтвами. Спираючись на концепцію У. Еко, ми досліджуємо проблему життя відкритого твору у процесах взаємодії мистецтв і виявляємо нові грані зв'язків між мистецтвами. Це, у свою чергу, дає можливість з нової точки зору розглянути художню культуру кінця XIX - початку XX століття в цілому та симфонічні твори С. Рахманінова, М. Регера та А. Халлена зокрема.

Ключові слова: відкритий твір, А. Беклін, картина «Острів мертвих», С. Рахманінов, симфонічна поема, творча біографія, взаємодія мистецтв. 
Kirdeeva Maya. The painting «Isle of the Dead» by Arnold Beklin as an open piece of art in music culture of the firms of the XIXth and XXth centuries. Relevance of the study. A significant change in the vectors of our perception and, consequently, an understanding and explanation of cultural processes of different times stimulated the search for new, non-obvious connections between the arts, existing concepts, etc.

Main objective of the study. Based on the concept of an open work by $\mathrm{U}$. Eco, we want to explore the problem of the life of an open work in the processes of interaction between the arts and explore the plot of A. Beklin's «Isle of the Dead» in creative biographies of the artist himself and composers in the context of synchronous cultural processes, as well as stylistic and ideological content interaction. This, in turn, makes it possible from a new point of view to look at the artistic culture of the late XIX - early XX century in general, and on the symphonic works by S. Rachmaninoff, M. Reger and A. Hallen.

The research methodology is based on the key provisions of the concept of the open piece of U. Eco [29], the concept of cultural studies of creative biographies, the problem of wandering artists and the concept of cultural commentary that were developed by S. Tyshko [21;22]. We applied the basic provisions of the phenomenon of monochrome images $[6 ; 13]$ and the interaction of various style trends $[10 ; 11 ; 12 ; 17 ; 20]$.

Results and conclusions. In our research we have studied a few things. Firstly, the concept of Umberto Eco's open piece and its importance for art culture, for cultural studies as a science and, accordingly, considered painting «Isle of the Dead» in this vein of issues. Secondly, we defined the creation history of Arnold's Beklin painting «Isle of the Dead» in his art and in five variants of its existence (1883-1888). Analyzed the main sources of research plot of this picture and have found its influence on the artist's work. Thirdly, working with the epistolary heritage and with the monographic literature about S. Rachmaninoff and A. Beklkin has helped to describe the story of the composer's acquaintance with the painting «Isle of the Dead» in German cultural centers, set its original version to create the eponymous symphonic poem and determine the role of its monochrome embodiment in the musical interpretation. In the end, we analyzed «Isle of the Dead» from Reger's «Beklin-Suite» and the symphonic poem by A. Hallen, explored the individual creative style of musicians and their view on the work of art in the features of musical solutions.

As a result, we confidently assert that the painting «Isle of the Dead» by A. Beklin has the significance most important cultural phenomenon and a vivid example of an open piece, with its inherent ability of many interpretations. 
Key words: open piece, A. Beklin, painting «Isle of the Dead», S. Rachmaninov, symphonic poem, creative biography, interaction of arts.

Кирдеева Майя. Картина Арнольда Бёклина «Остров мертвых» как открытое произведение в музыкальной культуре рубежа XIXХХ веков. Актуальность исследования. Существенное изменение векторов нашего восприятия и, соответственно, понимание и объяснение культурных процессов разных времен стимулировали поиск новых, неочевидных связей между искусствами, существующими концепциями и тому подобное. Опираясь на концепцию У.Эко, мы хотим исследовать проблему жизни открытого произведения в процессах взаимодействия искусств. Также, целью нашего исследования является изучение сюжета картин А. Бёклина «Остров мертвых» в творческих биографиях самого художника и композиторов в контексте синхронных культурных процессов. Особенно для нас важно их стилистическое и идейносодержательное взаимодействия. Это, в свою очередь, дает возможность с новой точки зрения взглянуть на художественную культуру конца XIX начала XX века в целом, и на симфонические произведения С. Рахманинова, М. Регера и А. Халлен в частности.

Методология исследования базируется на ключевых положениях концепции открытого произведения У.Эко [29], теории культурологических исследований творческих биографий, проблемы странствий художников и методе культурологического комментария, которые были разработаны С. Тышко [21; 22]. Также применены основные положения исследования феномена монохромных изображений [6;13] и взаимодействия различных стилевых тенденций $[10 ; 11 ; 12 ; 17 ; 20]$.

Кроме этого, мы применяем компаративистский подход, который заключается в сравнении между собой пяти вариантов картины «Остров мертвых» А. Бёклина и дает возможность заметить в них вполне определенную динамику развития.

Pезультаты и вblводы. В нашем исследовании мы, во-первых, изучили концепцию открытого произведения У.Эко, ее значение для художественной культуры, для культурологии как науки и, соответственно, картину «Остров мертвых» в данном русле проблематики. Во-вторых, мы определили историю создания картины «Остров мертвых» А. Бёклина в творчестве художника и в пяти вариантах ее существования (1883-1888 гг.). Проанализировали основные источники исследования сюжета этой картины и обнаружили ее влияние на творчество художника. В-третьих, работа с эпистолярным наследием и с монографической литературой о С. Рахманинове и А. Бёклине помогла очертить историю 
знакомства композитора с картиной «Остров мертвых» в немецких культурных центрах, установить ее оригинальный вариант для создания одноименной симфонической поэмы и определить роль ее монохромного воплощения в музыкальной интерпретации. Мы проанализировали «Остров мертвых» из «Бёклин-сюиты» М. Регера и симфоническую поэму А. Халлена, изучили индивидуальный творческий почерк музыкантов и их музыкальное решение данного произведение изобразительного искусства.

В итоге, мы с уверенностью утверждаем, что картина «Остров мертвых» А. Бёклина имеет значение важнейшего явления культуры и яркого примера открытого произведения, с присущей ему возможностью множества трактовок и интерпретаций.

Ключевые слова: открытое произведение, А. Бёклин, картина «Остров мертвых», С. Рахманинов, симфоническая поема, творческая биография, взаимодействие искусств.

Bcmyn. Суттєва зміна векторів нашого сприйняття та, відповідно, розуміння та пояснення культурних процесів різних часів стимулювали пошук нових, неочевидних зв'язків між мистецтвами. Спираючись на концепцію У.Еко, ми досліджуємо проблему життя відкритого твору у процесах взаємодії мистецтв і виявляємо нові грані зв'язків між мистецтвами. Це, у свою чергу, дає можливість з нової точки зору розглянути художню культуру кінця XIX - початку XX століття в цілому та симфонічні твори С. Рахманінова, М. Регера та А. Халлена зокрема.

Зображення швейцарського художника А. Бекліна сповнені магічної забарвленості та недомовленості. Найбільше ця таємнича сутність проявилася в його картині, що стала свого часу іконою символізму як стильового напрямку - «Острові мертвих» (1880-1886). Ї̈̈ сюжет стимулює різні прочитання, народжує нові спроби індивідуальноавторської інтерпретації візуально сприйнятих образів. Це і визначило актуальність цього дослідження, присвяченого розгляду картини А. Бекліна «Острів мертвих» як відкритого твору в музичних втіленнях С. Рахманінова, М. Регера та А. Халлена у контексті взаємодії мистецтв в художній культурі початку ХХ століття. Наукова і теоретична новизна полягає в застосуванні вперше в музичній культурології концепції відкритого твору до картини А. Бекліна «Острів мертвих» та їі однойменних музичних інтерпретацій, а також в дослідженні історії знайомства 3 нею С. Рахманінова та М. Регера в німецьких культурних центрах та встановлення ii вихідного варіанту для створення однойменних симфонічних поем. 
Метою нашого дослідження $\epsilon$ вивчення долі сюжету картин А. Бекліна «Острів мертвих» у творчих біографіях самого художника та композиторів в контексті синхронних культурних процесів. Особливо важливою для нас $є$ їх стилістична та ідейно-змістовна взаємодія.

Методологія дослідження базується на ключових положеннях культурологічної концепції відкритого твору У. Еко [29]. Як культурологічні інструменти вивчення життя «Острова мертвих» в образотворчому та музичному мистецтві ми використовували теорії взаємодії мистецтв [5; 19] і синтезу мистецтв [3; 15; 24; 25; 27; 28].

Матеріал статті також базується на теоріях культурологічних досліджень творчих біографій, культурологічного коментаря, проблеми мандрів митців, що були розроблені С. Тишком [21; 22]. Також застосовані основні положення дослідження феномену дзеркала в культурі, феномену монохромних зображень [6; 13], взаємодії різних стильових тенденцій $[10 ; 11 ; 12 ; 17 ; 20]$.

Крім того, ми застосовуємо компаративістський підхід: порівняння п’яти варіантів картин «Острів мертвих» А. Бекліна між собою, а також 3 монохромним офортом М. Клінгера, що дає можливість помітити в них чітко визначену динаміку розвитку.

Результати. Серед майстрів європейського символізму кінця XIX століття швейцарський художник Арнольд Беклін (1827-1901) безсумнівно мав славу однієї 3 найяскравіших постатей. Його пізні композиції, де фантастична символіка поєднується 3 натуралістичною достовірністю деталей, дали поштовх югендштилю ${ }^{1}$ в європейській художній культурі початку XX століття.

Як відомо, концепція відкритого твору була запропонована У. Еко не тільки для осмислення досвіду авангардного мистецтва, а й для всього мистецтва загалом - у всьому різноманітті епох, форм, жанрів, стилів і т.п.

Особливу увагу звернемо на те, що У. Еко спеціально фіксує цікавий аспект власної концепції: наприкінці епохи романтизму, з другої половини XIX століття, вперше з'являється цілком усвідомлена поетика відкритого твору в символізмі. Доречно нагадати, що картину А. Бекліна «Острів мертвих» дослідники якраз і відносять до символізму. Саме цей напрямок, на

\footnotetext{
${ }^{1}$ Югендштиль (нім. Jugendstil «молодий стиль» - за назвою ілюстрованого журналу Jugend, заснованого 1896 року) - художній напрям в архітектурі, декоративноприкладному мистецтві, найбільш поширений в останньому десятилітті XIX - на початку XX століття. Головними рисами югендштилю є відмова від прямих ліній i кутів на користь більш природних ліній, інтерес до нових технологій. [16, с. 118].
} 
нашу думку, є одним з найбільш наповнених і «відкритих» для реципієнта, що дає можливість існуванню безлічі трактувань та інтерпретацій.

Картина А. Бекліна стала своєрідним стартом (i хронологічно, i сюжетно, i образно) для іiі подальших інтерпретацій в різних видах мистецтв:

- в архітектурі (могили Г. Ліона на Введенському кладовищі в Москві і Г. Баумайстера на Смоленському кладовищі в СанктПетербурзі, а також поромна переправа на острів-усипальницю Людвігштайн у Виборзі);

- у живописі («Істинне зображення “Острова мертвих” Арнольда Бекліна в годину вечірньої молитви» (1932) С. Далі);

- у літературі (роман «Острів мертвих» (1969) Р. Желязни, вірш «Острів Бекліна» (2008) Е. Парнова);

- у театрі (декорації за мотивами картини Бекліна до опери Р. Вагнера «Валькірія» (1980, Байройт) в постановці П. Шеро);

- у кіномистецтві («Острів мертвих» (1945, жахи), режисер М. Робсон; «Острів мертвих» (1992, сюрреалістичний фільм-колаж), режисер О. Ковалов; «Чужий: Заповіт» (2017, кінофантастика / трилер), режисер Р. Скотт).

Надзвичайно важливим $є$ питання про те, яким чином відбувається інтерпретація сюжету Бекліна в музичному мистецтві. Слід зазначити, що музичних творів, написаних на цей мотив, виявилося досить багато, назвемо основні: симфонічні поеми «Острів мертвих» А. Халлена, Х. Шульца-Бойтена, С. Рахманінова, Ф. Войрша, М. Регера та органні твори Д. д’Антальфі та Ф. Любріша молодшого ${ }^{1}$. Таким чином, всі інтерпретаторські спроби підтверджують зацікавленість картиною та іiі важливе значення для історії культури.

У. Еко стверджує, що поняття відкритого твору не має аксіологічного значення. У своїх нарисах він не прагне до того, щоб розділити твори мистецтва на значимі («відкриті») та застарілі («закриті»). Натомість дослідник вважає, що «відкритість розуміється як принципова неоднозначність художнього повідомлення, характерна для будь-якого твору в будь-який час» [14, с. 53]. У. Еко пояснює: «Йдеться про відкритий твір як твір, що визначається “полем” різних інтерпретаційних можливостей, про твір, який постає як певна конфігурація стимулів, наділених принциповою невизначеністю, так, що людина, яка його сприймає, залучається до цілої низки “прочитань", причому завжди

\footnotetext{
${ }^{1}$ Імена композиторів подані в хронологічному порядку звернень до даного сюжету.
} 
мінливих; нарешті, мова йде про структуру як “сузір'я” елементів, які можуть вступати у різні взаємини» [14, с. 199].

Відомо, що картина А. Бекліна «Острів мертвих» існує в п’яти варіантах. Усі варіанти картини відрізняються один від одного за розмірами, технікою, кольоровою гамою, освітленням тощо. Відмінні риси між ними помітні в нових відтінках настрою - від похмурої безнадії до просвітленого трагізму. I ось тут ми зустрічаємося 3 випадком композиторського осмислення загального змісту всієї серії картин, коли в симфонічній поемі «Острів мертвих» С. Рахманінов створює цілу повість, в якій тихий спокій приходить на зміну глибокій скорботі. Таке творче рішення композитора повторює колізію, яка помітна в еволюції сюжету серії картин А. Бекліна.

$\begin{array}{llllll}\text { Робота } 3 \text { епістолярною спадщиною } & \text { С. Рахманінова та } 3\end{array}$ монографічною літературою допомогла нам вперше в дослідженні творчої біографії митця встановити хронологію його ознайомлення 3 деякими варіантами картин А. Бекліна, а в підсумку - що найважливіше! - виявити, який 3 них став живописною «матрицею» для створення симфонічної поеми. Відразу слід зауважити, що мистецтвознавці давали на це запитання помилкову відповідь. Наприклад, Ю. Келдиш пише: «У травні 1907 року в Парижі, де він перебував у зв'язку зі своєю участю в Російських історичних концертах, Рахманінов познайомився 3 репродукцією картини Бекліна, що стала джерелом його симфонічного задуму» [8, с. 318]. Такої точки зору дотримується і В.Брянцева, стверджуючи, що «картина Бекліна зацікавила композитора у травні 1907 року, в Парижі, своєю чорно-білою репродукцією» [2, с. 394]. Однак зовсім іншого погляду дотримуються дослідники творчості А. Бекліна. Наприклад, мистецтвознавець М. Аграновська пише про те, що «Сергій Рахманінов, знаходячись під глибоким враженням від картини, п’ятий варіант якої він бачив у Лейпцигу, написав 1909 року симфонічну поему “Острів мертвих" (всього в 1890-1910 рр. в Свропі було створено п’ять музичних творів, натхнених цією картиною)» [1]. Все це викликало необхідність самостійного «розслідування» в цій галузі.

Сам С. Рахманінов ясно пише про місце, де він побачив репродукцію, а пізніше і оригінал «Острова мертвих» А. Бекліна: «Вперше я побачив в Дрездені тільки копію чудової картини Бекліна. Масивна композиція і містичний сюжет цієї картини справили на мене велике враження, і це визначило атмосферу поеми. Пізніше в Берліні я побачив оригінал картини» ${ }^{1}[4$, с. 398]. 3 цього стає зрозуміло, у яких конкретно містах С. Рахманінов побачив репродукцію картини і їі оригінал, а саме: у

\footnotetext{
${ }^{1}$ Тут і далі переклад українською мовою автора статті.
} 
Дрездені - репродукцію, у Берліні - оригінал, що істотною мірою відрізняється від тверджень дослідників, наведених вище.

Відомо, що третю версію «Острова», яку ми визначаємо як опорну, А. Беклін виконав на замовлення берлінського колекціонера і видавця Ф. Гурлітта. Рахманінов стверджує, що побачив оригінал картини саме в Берліні. Отже, саме на виставці колекції Ф. Гурлітта композитор познайомився з оригіналом картини. Повертаючись до питання про те, яка чорно-біла репродукція, і якого саме варіанту картини, так вразила С. Рахманінова, ми дозволимо собі стверджувати, що це була чорно-біла репродукція третього варіанту картини. Адже 1890 року відомий графік М. Клінгер ${ }^{1}$ проєктує офорт, що відтворює третій варіант «Острова», а власник картини, вже відомий нам Ф.Гурлітт, випускає цей офорт величезним тиражем. Таким чином, «Острів мертвих» завойовує всю Європу! Саме цей офорт і побачив С. Рахманінов в Дрездені. Він і стає джерелом створення однойменної симфонічної поеми.

Той факт, що С. Рахманінова надихнула саме чорно-біла репродукція картини А. Бекліна, спонукав нас до аналізу такого примітного явища, як феномен монохромних зображень, який ми свого часу розглядали, спираючись на дослідження М. Пастуро та В. Кандинського 2 [6; 13]. 3 цього приводу наведемо один цікавий біографічний факт. Ось як висловлювався Сергій Васильович про своє враження від чорно-білої репродукції А. Бекліна: «У фарбах вона не особливо схвилювала мене. Якби я спочатку побачив оригінал, то, можливо, не створив би свого "Острова мертвих". Картина мені більше подобається в чорно-білому вигляді» [14, с. 398].

Отже, для С. Рахманінова постала важливою не мальовнича барвистість, безсумнівно присутня в оригіналі картини, а метафоричність чорно-білої репродукції, ऑiі буттєва художня ідея. На відміну від однородного колориту беклінівського полотна, другий розділ симфонічної поеми різко контрастний музичній атмосфері крайніх розділів. Підтвердженням цього може слугувати одне 3 висловлювань самого С. Рахманінова про тему першого епізоду другого розділу поеми: «Вона повинна бути величезним контрастом до всього іншого, іiі треба виконувати швидше, більш нервово та емоційно: оскільки це місце не пов'язане з образом “картини”, воно в дійсності свого роду доповнення до

\footnotetext{
${ }^{1}$ Макс Клінгер (Max Klinger, 1857-1920) - німецький художник-живописець, графік і скульптор. Творчість Макса Клінгера $є$ своєрідною сполучною ланкою між символічним рухом XIX століття і початку розвитку метафізичного і сюрреалістичного рухів XX століття. Макс Клінгер увійшов до історії європейського мистецтва як один 3 яскравих представників раннього стилю модерн [23, с. 36].

2 Див.: дипломна робота автора [7].
} 
неї, і тому контраст надзвичайно необхідний. Спочатку - смерть, потім життя» [18, с. 98-99]. Наявність контрастного матеріалу в симфонічній поемі є наслідком зовсім іншої, відмінної від А. Бекліна, художньої ідеї. Не таємниця смерті, що зображена художником, а таємниця життя, немов загубленого в океані мертвої матерії, втілена в поемі С. Рахманінова.

Щоб встановити достовірно, який варіант картини «Острів мертвих» побачив вперше німецький композитор М. Регер, ми звертаємося до дослідника його творчої біографії Ю. Шалтупера [26]. Він відзначає, що $з$ 1907 року М. Регер проживав у Лейпцигу, де займав посаду музичного директора в університеті, керував класом композиції в консерваторії та придворною капелою у Мейнінгені. Отже, ми можемо припустити, що М. Регер, тривалий час перебуваючи в Лейпцигу, міг бачити саме п'ятий варіант картини А. Бекліна «Острів мертвих», який був написаний художником для Музею витончених мистецтв в Лейпцигу та слугував творчим стимулом для написання композитором однойменної симфонічної поеми з «Беклін-сюїти» (1913).

Досліджуючи історію картини «Острів мертвих», ми помічаємо важливу тенденцію руху цього твору. Говорячи про рух, маємо на увазі його перехід від варіанту до варіанту, від культури в культуру, від редакції до редакції, від художника до художника. Рух від варіанта до варіанта мається на увазі трансформація ідеї та іiі художнє вираження в картинах А. Бекліна «Острів мертвих» в переході від одного варіанта до іншого. Говорячи про рух від культури в культуру, розуміємо перехід, i, одночасно, зв'язок культур - швейцарської, німецької та російської в даному випадку. Рух від художника до художника передбачає передачу основної ідеї «Острова мертвих» від художника до графіка (мова йде про М. Клінгера), від графіка до композитора, від композитора до диригента, від диригента до оркестру. Поняття «т в ір у русі» трактується У. Еко як одна з форм відкритого твору. «Твори в русі, ознака того, що певні вимоги витають в повітрі, що вони виправдовуються самим фактом свого існування i що їх треба пояснювати як феномени культури, що доповнюють один одного в панорамі епохи» [29, с. 89]. Для нас це важливо, тому що «твір у русі» ми вважаємо цікавим феноменом культури і розглядаємо «Острів мертвих» як його яскраве вираження.

На наш погляд, саме на прикладі образу води ми можемо продемонструвати як деякі риси спільності в інтерпретації композиторами, так і суттєві розбіжності. Початковий розділ «Острова мертвих» С. Рахманінова представляє картину безмежного морського простору, мертвої гладі. Основною його темою, власне, і є тема «водної стихії», 
триразове повторення якої і формує логіку композиції. Однак, образ моря у С. Рахманінова є статичним і знаходиться в межах єдиної гами емоційного стану. Поступове кількісне поповнення числа інструментів і акустичне посилення потужності, обсягу звукового простору, що супроводжує нову появу теми води, не дають якісної зміни, а позначають лише наближення до слухача, зміну його просторової координати. Музикознавець І. Корякіна зазначає: «"Віхами” “шляху” стають нові тематичні утворення (тема “таємничого поклику”, хорал мідно-духових інструментів, середньовічна секвенція "Dies irae"). Кожне 3 представлених тематичних утворень асоціюється у слухача 3 безособовим началом. "Море" в “Острові мертвих" - це не межа між життям і смертю, а власне мертва зона, мертвий простір, що омиває з двох сторін (перший розділ і коду) сам “острів" (другий розділ поеми)» [9, с. 39].

В «Острові мертвих» 3 «Беклін-сюїти» М. Регер постійно використовує крайні динамічні градації, які несподівано чергуються між собою та мають вибуховий характер 3 яскравою зміною динаміки $\mathrm{i}$ темповим зрушенням. Тут чітко промальовані два різко контрастних образи. А на картині А. Бекліна вони втілюються в протиставленні горизонтальної (спокійне море) і вертикальної (витягнуті вгору скелі, величезні кипариси) ліній. Так само і в музиці, море змальовано похмурими фарбами в нижніх регістрах: ті ж повільні темпи, перетікання 3 одного дисонуючого співзвуччя в інше; острів ніби обрушується на цей горизонтальний спокій 3 верхніх регістрів усією міццю туттійного звучання.

Порівняно 3 «Островом мертвих» С. Рахманінова і М. Регера симфонічна поема шведського композитора А. Халлена є світлішою та життєстверджуючою. Як основний музичний елемент він використовує ритм баркароли, що м'яко пульсує у розмірі $12 / 8$, зображуючи рух човна по воді. Головна мелодійна тема створює настрій спокою та світлої печалі. А це робить музику Халлена повною надії, ніби митець змальовує «обітовану» землю, яка знаходиться за межами боротьби й пристрасті.

С. Рахманінов, М. Регер й А. Халлен, вражені картиною А. Бекліна «Острів мертвих», створюють музичні твори, в яких помітна ідея взаємодії мистецтв. Живопис і музика, у цьому випадку, вступають в нерозривний зв'язок один 3 одним. Для художньої культури сучасного суспільства однією 3 провідних закономірностей $є$ тенденція до розвитку видів мистецтв як єдиної системи. Можна навести безліч прикладів того, як художник гармонійно поєднує кілька видів мистецтв, щоб втілити свою ідею, наприклад, в перформансі. Взаємодія між ними служить розширенню горизонтів кожного з мистецтв, поглибленню пізнання світу. 
Знайомлячись 3 картиною А. Бекліна, глядач розширює своє пізнання через осмислення античного міфу про Харона, що везе покійного на острів. Глядач може сам трактувати, що саме ховається за символом острова, хто є Харон і покійний, і що відбувається за стінами фортеці. С. Рахманінов та М. Регер передають у музиці емоційну атмосферу цього міфу. Знаходячи і розшифровуючи ці символи для себе, глядач, за допомогою взаємодії цих видів мистецтв, поглиблює своє пізнання світу.

Без перебільшення можна сказати, що XX століття дало новий подих, плідний імпульс розвитку світової культури. Концепція митців щодо синтезу мистецтв нерозривно пов'язана 3 їх світовідчуттям, 3 дослідженням внутрішнього світу художника, з філософським розумінням ролі мистецтва i закономірностей розвитку художньої культури. Розмірковуючи про поліфонізм різних тенденцій в мистецтві на межі XIX-XX століть, М. Швець наводить вислів I. Буніна: «Ми пережили і декаданс, i символізм, і натуралізм, і порнографію, що називається дозволом “проблеми статі”, i богоборство, i міфотворчість, і якийсь містичний анархізм, і Діоніса, і Аполлона, i “польоти у вічність”, і садизм, i снобізм, i “прийняття світу”, i “неприйняття світу”, і лубочні підробки під російський стиль, і адамізм, і акмеїзм та дійшли до самого плоского хуліганства, званого “футуризм”» [27, с. 57]. Таким чином, безліч різних художніх тенденцій i стилів спричиняють поєднання різних видів мистецтв та художній синтез, які виступають інструментами в передачі художнього сенсу творів мистецтва.

Висновки. Підводячи підсумки, можемо стверджувати, що інтенсивність мистецького життя ХX століття та тенденція пошуку нових смислів спричинила i пошук відкритості 3 iï безліччю трактувань. Художники намагалися розширити коло сприйняття власних творів, знайти ті засоби вираження, які допоможуть «відшукати» реципієнту ті закладені смисли, що містяться в їх ідеях. Виходячи з цього, безліч різних художніх тенденцій і стилів спричиняють взаємодію різних видів мистецтв та їх художній синтез, які, в свою чергу, виступають інструментами в передачі художнього сенсу творів мистецтва.

Отже, у нашому дослідженні ми, по-перше, вивчили концепцію відкритого твору У. Еко, iї значення для художньої культури, для культурології як науки і, відповідно, представили картину «Острів мертвих» у цьому аспекті проблематики. По-друге, ми окреслили історію створення картини «Острів мертвих» А. Бекліна в творчості художника і в п’яти варіантах ii існування (1883-1888 pp.). Проаналізували основні джерела дослідження сюжету цієї картини і виявили іiі вплив на творчість 
художника. По-трете, робота з епістолярною спадщиною і з монографічною літературою про С. Рахманінова і А. Бекліна допомогла окреслити історію знайомства композитора 3 картиною «Острів мертвих» в німецьких культурних центрах, встановити іï оригінальний варіант для написання однойменної симфонічної поеми та визначити роль іï монохромного втілення в музичній інтерпретації. Насамкінець, ми проаналізували «Острів мертвих» 3 «Беклін-сюїти» М. Регера та симфонічну поему А. Халлена, вивчили індивідуальний творчий почерк музикантів та їх погляд на твір образотворчого мистецтва в особливостях музичного рішення.

Тож, підсумком проведеного дослідження стає незаперечний факт широкої відкритості сюжету картини «Острів мертвих» А. Бекліна для музичного втілення С. Рахманіновим, М. Регером та А. Халленом з погляду тенденцій взаємодії мистецтв у художній культурі початку ХХ століття.

1. Аграновская М. Арнольд Бёклин. Остров мертвых // «Партнер» : журнал. № 10 (145). Дортмунд, 2009. С. 34-41.

2. Брянцева В. Сергей Васильевич Рахманинов : монография / под ред. А. Курцман. Москва, 1976. 680 с.

3. Ванечкина И., Галеев Б. Концепция синтеза искусств А. Н. Скрябина // Материалы всесоюзной школы молодых ученых по проблеме «Свет и Музыка» (третья конференция). Казань, 1975. С. 24-30.

4. Воспоминания о Рахманинове : в 2 т. Том 1 / сост., ред., коммент., указ. З. Апетян. Москва : Музыка, 1988. 528 с.

5. Каган М. Морфология искусства : Историко-теоретическое исследование внутреннего строения мира искусств. Москва : Искусство, 1972. 440 с.

6. Кандинский В. О духовном в искусстве (живопись) : монография. Москва : ЭКСМО, 2016. $160 \mathrm{c}$.

7. Кірдеєва М. Картина А. Бекліна «Острів мертвих» як відкритий твір в музичних втіленнях С. Рахманінова та М. Регера: тенденції взаємодії мистецтв у художній культурі початку XX століття : дип. робота магістра культурогогії: 24.00.01/ НМАУ ім. П. І. Чайковського. Київ, 2018. 110 с.

8. Келдыш Ю. В. Рахманинов и его время : монография. Москва, 1973. 432 с.

9. Корякина И. С. В. Рахманинов. Симфоническая поэма «Остров мёртвых»: «встреча» с А. Беклиным - «встреча» с символизмом? // Вопросы истории культуры. № 3. 1999. Издательство Уральского университета. С. 37-46.

10. Михайлов М. Стиль в музыке : исследование. Ленинград, 1981. 262 с.

11. Медушевский В. Музыкальный стиль как семиотический объект // Советская музыка. № 3. Москва, 1979. С. 30-39.

12. Назайкинский Е. Стиль и жанр в музыке : учеб. пособие для студ. высш. учеб. завед. Москва : Гуманит. изд. центр Владос, 2003. 248 с.

13. Пастуро М. Синий. История цвета / пер. с фр. Н. Кулиш. Москва : Новое литературное обозрение, 2017. 144 с.

14. Рахманинов С. В. Письма / ред., вступ. ст. и коммент. 3. Апетян. Москва : Музгиз, $1955.603 \mathrm{c}$.

15. Сабанеев Л. Скрябин : монографический очерк. Москва, 1923. 322 с.

16. Сарабьянов Д. Стиль Модерн. Истоки. История. Проблемы : в 2 ч. Часть 2. Москва : Искусство, 1989. 294 с. 
17. Скребков С. Художественные принципы музыкальных стилей. Москва, 1973. 368 с.

18. Соколова О. Симфонические произведения С. В. Рахманинова / ред. Т. Коровина. Москва : МУЗГИЗ, 1957. 132 с.

19. Степанов Г. Взаимодействие искусств. Ленинград : Художник РСФРС, 1973. 184 с.

20. Тышко С. В. Проблема национального стиля в русской опере. Глинка. Мусоргский. Римский-Корсаков : Исследования. Киев, 1993. 120 с.

21. Тышко С., Мамаев С. Странствия Глинки : Комментарий к «Запискам» : в 4 ч. Ч. 1 : Украина. Киев, 2004. 216 с.

22. Тышко С. В., Куколь Г. В. Странствия Глинки : Комментарий к «Запискам» : в 4 ч. Ч. 3. Киев : Клякса, 2011. 544 с.

23. Федотова Е. Арнольд Бёклин. Москва : Белый город, 2001. 64 с.

24. Флоренский П. А. Храмовое действо как синтез искусств / сост. А. С. Трубачев, В. В. Бычков. Москва : Изобразительное искусство, 1996. 335 с.

25. Чібалашвілі А. О. Художній синтез у музичній творчості як знак новітнього // ARTКУРСИВ. № 4. 2010. С. 18-26.

26. Шалтупер Ю. Заметки о Максе Регере // Советская музыка. № 12. 1973. С. 94-101.

27. Швец Н. Культурологический синтез как стилеобразующий фактор в музыкальном искусстве рубежа XIX-XX столетий (на примере творчества С. Танеева и Н. Метнера) : дисс. ‥ канд. искусствоведения : 17.00.03 / Национальная музыкальная академия Украины им. П. И. Чайковского. Киев, 2008. 254 с.

28. Шеллинг Ф. Философия искусства. Москва : Мысль, 1966. 458 с.

29. Эко У. Открытое произведение : Форма и неопределенность в современной поэтике / пер. с итал. А. Шурбелева. Санкт-Петербург : Symposium, 2006. 412 с.

\section{References}

1. Agranovskaya, M. (2009). Arnold Beklin. Isle of the Dead. Partner, 10 (145), pp. 34-41 [in Russian].

2. Bryantseva, V. (1976). Sergey Vasilyevich Rakhmaninov. A. Kurtzman (Ed.). Moscow [in Russian].

3. Vanechkina, I., Galeev, B. (1975). The concept of the synthesis of the arts of A. N. Scriabin. In: Proceedings of the All-Union School of Young Scientists on the Problem "Light and Music» (third conference). Kazan, pp. 24-30 [in Russian].

4. Apetyan, Z. (Ed.) (1988). Memories of Rachmaninov. Vol. 1, Moscow: Muzyka [in Russian].

5. Kagan, M. (1972). The morphology of art. Moscow: Art [in Russian].

6. Kandinsky, V. (2016). On the spiritual in art (painting). Moscow: EKSMO [in Russian].

7. Kirdeeva, M. (2018). Painting «Isle of the Dead» by A. Beklin as an open piece of art in music pieces by $S$. Rachmaninov and M. Reher: tendencies of arts interaction in culture of the early XXth century. Master's degree thesis. Ukrainian National Tchaikovsky Academy of Music. Kyiv [in Ukrainian].

8. Keldysh, Y. (1973). Rachmaninov and his time. Moscow: Muzyka [in Russian].

9. Koryakina, I. (1999). S. V. Rachmaninov. Symphonic poem «The Island of the Dead»: «meeting» with A. Beklin - «meeting» with symbolism? Voprosy istorii kultury, 3, pp. 37-46 [in Russian].

10. Mikhailov, M. (1981). Style in music. Leningrad: Music [in Russian].

11. Medushevsky, V. (1979). Musical style as a semiotic object. Soviet music, 3, pp. 30-39 [in Russian].

12. Nazaikinsky, E. (2003). Style and genre in music. Moscow: Vlados [in Russian].

13. Pasturo, M. (2017). Blue. History of the color. N. Kulish (Trans.). Moscow: Novoye literaturnoye obozreniye [in Russian].

14. Apetyan, Z. (Ed.) (1955). S. V. Rachmaninov. Letters. Moscow: Muzgiz [in Russian].

15. Sabaneev, L. (1923). Scriabin: monographic sketch. Moscow [in Russian]. 
16. Sarabyanov, D. (1989). Style Modern. Origins. Story. Problems. Part 2. Moscow: Iskusstvo [in Russian].

17. Skrebkov, S. (1973). Artistic principles of musical styles. Moscow [in Russian].

18. Sokolova, O. (1957). Symphonic works by S. V. Rakhmaninov. T. Korovina (Ed.). Moscow: MUZGIZ [in Russian].

19. Stepanov, G. (1973). Interaction between the arts. Leningrad: Khudozhnik RSFSR [in Russian].

20. Tyshko, S. (1993). The problem of national style in the Russian opera. Glinka. Mussorgsky. Rimsky-Korsakov. Kyiv [in Russian].

21. Tyshko, S., Mamaiev, S. (2004). Glinka's wanderings. Commentary on «Notes». Vol. 1. Kyiv [in Russian].

22. Tyshko, S., Kukol, G. (2011). Glinka's wanderings. Commentary on «Notes». Vol. 3. Kyiv [in Russian].

23. Fedotova, E. (2001). Arnold Böcklin. Moscow [in Russian].

24. Florensky, P. (1996). Temple action as a synthesis of arts. A. Trubachev, V. Gobies (Eds.). Moscow: Izobrazitelnoye iskusstvo [in Russian].

25. Chealashvili, A. (2010). Artistic synthesis of musical creativity as a sign of a new hour. ART-CURSIV, 4, pp. 18-26 [in Ukrainian].

26. Shaltuper, Y. (1973). Notes on Max Reger. Sovetskaya muzyka, 12, pp. 94-101 [in Russian].

27. Shvets, N. (2008). Culturological synthesis as a style-forming factor in the musical art of the turn of the nineteenth and twentieth centuries (on the example of the works by S. Taneyev and N. Medtner). PhD thesis. Ukrainian National Tchaikovsky Academy of Music. Kyiv [in Russian].

28. Schelling, F. (1966). Philosophy of Art. Moscow: Mysl [in Russian].

29. Eco, U. (2006). Open Piece: Form and uncertainty in modern poetics. A. Shurbeleva (Trans.). St. Petersburg: Symposium [in Russian].

УДК 784.087.68.083.2.071.2

DOI: https://doi.org/10.33643/kmus.2019.59.14

Ганна Харакоз, аспірантка кафедри теорії музики Харківського національного університету мистецтвв імені I. П. Котляревського https://orcid.org/0000-0002-4076-1264 kharakozhanna@gmail.com

Hanna Kharakoz,

Postgraduate at the Theory of Music Department, Kharkiv National I. P. Kotlyarevsky University of Arts https://orcid.org/0000-0002-4076-1264

kharakozhanna@gmail.com

\section{ХОРОВА ФУГА \\ ЯК ОБ'ЄКТ ХУДОЖНЬО-ВИКОНАВСЬКОЇ ІНТЕРПРЕТАЦЇ̈ (НА ПРИКЛАДІ «IN SEMPITERNA SAECULA, AMEN» 3 КАНТАТИ «STABAT MATER» ДЖОАККIНО РОССIHI)}

Aктуальність. Вперше здійснюється розгляд виконавської проблематики, пов'язаної із художніми завданнями, що постають в процесі 